
ISSN : 2615-1995, E-ISSN : 2615-0654

J. Madani., Vol. 3, No. 2, September 2020 (212 - 227)

(C)2018 Lembaga Kajian Demokrasi

dan Pemberdayaan Masyarakat (LKD-PM)

DOI : https://doi.org/10.33753/madani.v3i2.83

\title{
Analisis Rasio Tingkat Kesehatan Bank Menggunakan Metode CAMEL Pada PT Bank BCA Syariah Tbk Jakarta Timur Tahun 2013 - 2017
}

\author{
Supatmin \\ Fakultas Ekonomi, Universitas Pamulang \\ dosen01767@unpam.ac.id
}

\begin{abstract}
Abstrak
Tujuan penelitian ini untuk mengetahui perkembangan kesehatan bank pada PT Bank BCA Syariah Tbk dan untuk mengukur tingkat kesehatan PT Bank BCA Syariah Tbk pada tahun 2013-2017 dengan menggunakan rasio CAMEL yang meliputi aspek permodalan, aktiva produktif, manajemen, rentabilitas dan likuiditas. Penelitian ini bersifat deskriptif kuantitatif. Populasi dalam penelitian ini meliputi seluruh laporan keuangan PT Bank BCA Syariah periode tahun 2013 sampai dengan 2017, sedangkan sampel dalam penelitian ini adalah laporan keuangan perusahaan berupa neraca dan laporan laba rugi PT. Bank BCA Syariah Tbk. periode 2013 sampai dengan 2017. Analisis data yang digunakan dalam penelitian ini adalah dengan menggunakan metode CAMEL yang terdiri dari lima aspek, yaitu aspek permodalan menggunakan rasio CAR (Capital Adequacy Ratio), aspek kualitas aktiva produktif menggunakan rasio KAP (Kualitas Aktiva Produktif) dan PPAP (Penyisihan Penghapusan Aktiva Produktif), aspek manajemen menggunakan rasio NPM (Net Profit Margin), aspek rentabilitas menggunakan rasio ROA (Return On Assets) dan BOPO (Beban Operasional terhadap Pendapatan Operasional), dan aspek likuiditas menggunakan rasio NCM-CA (Net Call Money to Current Assets) dan LDR (Loan to Deposit Ratio). Berdasarkan hasil penelitan yang telah dilakukan pada PT Bank BCA Syariah CAMEL pada tahun 2013 97,04 adalah sehat, tahun 2014 96,71 adalah sehat, tahun 2015 95,52 adalah sehat, tahun 2016 97,01 adalah sehat, tahun 2017 98,00 adalah sehat.
\end{abstract}

Kata Kunci : Rasio Tingkat Kesehatan Bank, CAMEL

\begin{abstract}
The purpose of this study was to determine the development of bank health at PT Bank BCA Syariah Tbk and to measure the level of health of PT Bank BCA Syariah Tbk in 2013-2017 using the CAMEL ratio which includes aspects of capital, productive assets, management, profitability and liquidity. This research is quantitative descriptive. The population in this study includes all financial statements of PT Bank BCA Syariah for the period 2013 to 2017, while the sample in this study is the company's financial statements in the form of a balance sheet and income statement of PT. Bank BCA Syariah Tbk. period 2013 to 2017. Analysis of the data used in this study is to use the CAMEL method which consists of five aspects, namely capital aspects using CAR (Capital Adequacy Ratio), aspects of earning asset quality using the ratio of KAP (Earning Assets Quality) and PPAP (Allowance for Earning Assets), management aspects using the ratio of NPM (Net Profit Margin), profitability aspects using the ratio of ROA (Return On Assets) and BOPO (Operating Expenses to Operating Income), and the liquidity aspect using the NCM-CA (Net Call Money ratio) to Current Assets) and LDR (Loan to Deposit Ratio). Based on the results of research conducted at PT Bank BCA Syariah CAMEL in 201397.04 was healthy, in 201496.71 was healthy, in 201595.52 was healthy, in 201697.01 was healthy, in 201798.00 is healthy.
\end{abstract}

Keywords : Bank Soundness Ratio, CAMEL 


\section{PENDAHULUAN}

Pada masa sekarang terdapat beberapa lembaga keuangan. Salah satu di antara lembaga-lembaga keuangan tersebut yang tampaknya paling besar peranannya dalam perekonomian adalah lembaga keuangan bank, yang lazimnya disebut bank. Bank merupakan lembaga keuangan yang menjadi tempat bagi perusahaan, badan-badan pemerintah dan swasta, maupun perorangan menyimpan dana-dananya. Melalui kegiatan perkreditan dan berbagai jasa yang diberikan, bank melayani kebutuhan pembiayaan serta melancarkan mekanisme sistem pembayaran bagi semua sektor perekonomian.

Di Indonesia ini banyak kita jumpai bank, baik bank milik negara, swasta, pemerintah, atau yang lainnya. Bank berperan penting dalam mendorong perekonomian nasional karena bank merupakan penghimpun dana dari pihak-pihak yang memiliki kelebihan dana kepada pihak-pihak yang membutuhkan dana serta sebagai lembaga yang berfungsi memperlancar aliran lalu lintas pembayaran.

Pemberlakuan Undang-undang No. 10 Tahun 1998 tentang perubahan Undang-undang No. 7 Tahun 1992 tentang perbankan telah memberi kesempatan luas untuk pengembangan jaringan perbankan syariah. Selain itu Undang-undang No.23 Tahun 1999 tentang Bank Indonesia, telah menugaskan kepada Bank Indonesia mempersiapkan perangkat peraturan dan fasilitas-fasilitas penunjang yang mendukung operasional bank syariah. Kedua undang-undang tersebut menjadi dasar hukum penerapan dual banking sistem di Indonesia. Dual banking sistem yang dimaksud adalah terselenggaranya dua sistem perbankan (konvensional dan syariah) secara berdampingan, yang pelaksanaannya diatur dalam berbagai peraturan perundang-undangan yang berlaku.

Kegiatan usaha perbankan syariah pada dasarnya merupakan perluasan jasa perbankan bagi masyarakat yang membutuhkan dan menghendaki pembayaran imbalan yang tidak didasarkan pada sistem bunga, melainkan atas dasar prinsip syariah sebagaimana digariskan syariah (hukum) Islam. Menurut pasal 1 ayat (1) UU
Nomor 21 Tahun 2008 tentang perbankan syariah menyatakan "Perbankan Syariah adalah segala sesuatu yang menyangkut tentang Bank Syariah dan Unit Usaha Syariah, mencakup kelembagaan, kegiatan usaha, serta cara dan proses dalam melaksanakan kegiatan usahanya".

Dalam operasinya, bank Islam menggunakan sistem bagi hasil dan imbalan lainnya yang sesuai dengan syariah Islam. Kepercayaan masyarakat terhadap suatu bank tidak terlepas dari keadaan keuangan bank, termasuk kesehatan bank tersebut. Kinerja keuangan bank merupakan gambaran kondisi keuangan bank pada suatu periode tertentu baik mencakup aspek penghimpunan dana maupun penyaluran dananya. Kepercayaan dan loyalitas pemilik dana terhadap bank merupakan faktor yang sangat membantu dan mempermudah pihak manajemen bank untuk menyusun strategi bisnis yang baik. Sebaliknya para pemilik dana yang kurang menaruh kepercayaan kepada bank yang bersangkutan maka loyalitasnya pun sangat tipis, hal ini sangat tidak menguntungkan bagi bank yang bersangkutan karena para pemilik dana sewaktu-waktu dapat menarik dananya dan memindahkannya ke bank lain.

Sama seperti bank lainnya Perbankan Syariah juga harus diketahui kesehatannya. Kesehatan bank dapat diartikan sebagai kemampuan suatu bank untuk melakukan kegiatan operasional perbankan secara normal dan mampu memenuhi semua kewajibannya dengan baik dengan caracara yang sesuai dengan peraturan perbankan yang berlaku (Santoso: 2006). Pada tahun-tahun terakhir ini dunia perbankan syariah di Indonesia menunjukkan perkembangan yang sangat pesat, baik dilihat dari jumlah pembukaan kantor baru, jenis usaha bank dan volume kegiatan bank yang dilakukannya. Seiring dengan meningkatnya pertumbuhan ekonomi, pembiayaan perbankan syariah juga mengalami peningkatan yang tajam. Kualitas pembiayaan syariah juga menunjukkan kinerja yang membaik dengan ditunjukkan oleh membesarnya porsi pembiayaan bagi hasil yaitu mudharobah dan musyarokah.

Agar suatu bank dapat menjalankan seluruh kegiatannya dengan baik, maka tindakan yang perlu dilakukan adalah perencanaan, pengopera- 
sian, pengendalian, dan pengawasan. Proses aliran keuangan secara terus menerus dan peningkatan dari tahun ke tahun perlu dilakukan pencatatan dalam laporan keuangan yang terdiri dari neraca dan perhitungan rugi-laba. Pada mulanya laporan keuangan bagi suatu perusahaan hanyalah suatu alat penguji dari pekerjaan bagian pembukuan akan tetapi selanjutnya laporan keuangan tidak hanya sebagai alat penguji saja tetapi juga sebagai dasar untuk dapat menentukan atau menilai posisi atau kondisi keuangan perusahaan tersebut. Dimana dengan hasil analisa keuangan pihak-pihak yang berkepentingan seperti manajer, kreditur, dan investor dapat mengambil sesuatu kebijakan.

Berdasarkan laporan keuangan akan dapat dihitung sejumlah rasio keuangan yang lazim dijadikan dasar penilaian tingkat kesehatan bank. Analisis rasio keuangan memungkinkan manajemen untuk mengidentifikasikan perubahanperubahan pokok pada trend jumlah, dan hubungan serta alasan perubahan tersebut. Hasil analisis laporan keuangan akan membantu mengintepretasikan berbagai hubungan serta kecenderungan yang dapat memberikan dasar pertimbangan mengenai potensi keberhasilan perusahaan dimasa mendatang. Untuk menilai kinerja perusahaan perbankan umumnya digunakan aspek penilaian, yaitu: Capital, Assets, Management, Earnings, dan Liquidity yang biasa disebut CAMEL. Aspek-aspek tersebut menggunakan rasio keuangan. Hal ini menunjukkan bahwa rasio keuangan dapat digunakan untuk menilai tingkat kesehatan bank.

Dengan adanya analisa laporan keuangan dapat diketahui tingkat kinerja suatu bank, karena tingkat kinerja merupakan salah satu alat pengontrol kelangsungan usaha. Berdasarkan laporan keuangan, maka akan diketahui tingkat kinerja suatu bank (sehat atau tidak sehat). Menurut Kasmir (2008: 185-186), salah satu alat untuk mengukur kesehatan bank adalah dengan analisis CAMEL (Capital, Asset, Management, Earning, dan Liquidity). Aspek-aspek tersebut menggunakan rasio keuangan yang disajikan melalui laporan keuangan perusahaan yang di terbitkan setiap tahunnya.
Penilaian aspek Capital didasarkan kepada permodalan yang dimiliki oleh suatu Bank. Salah satu penilaian adalah dengan metode CAR (Capital Adequacy Rasio) yaitu dengan cara membandingkan modal terhadap aktiva tertimbang menurut resiko (ATMR). Penilaian Assets didasarkan kepada kualitas aktiva yang dimiliki Bank. Rasio yang diukur ada yaitu Rasio aktiva produktif yang diklasifikasikan terhadap aktiva produktif dan Rasio penyisihan penghapusan aktiva produktif terhadap aktiva produktif yang diklasifikasikan. Aspek Management didasarkan kepada manajemen permodalan, manajemen aktiva, manajemen rentabilitas, manajemen likuiditas dan manajemen umum yang diterapkan dalam kebijakan usaha bank. Penilaian Earning didasarkan kepada rentabilitas suatu bank yaitu melihat kemampuan suatu bank dalam menciptakan laba dalam setiap tahunnya. Penilaian dalam unsur ini didasarkan kepada Rasio laba terhadap total aset (Return on Assets) dan Rasio beban operasional terhadap pendapatan operasional (BOPO). Penilaian Liquidity mengukur tingkat likuiditas suatu bank. Adapun penilaian didasarkan kepada 2 macam rasio yaitu Ratio Net Call Money to Current Assets dan Rasio antara kredit terhadap dana yang diterima oleh Bank (Financing to Deposit Ratio). Menurut Dendawijaya (2009:143), tata cara penilaian tingkat kesehatan bank dengan menggunakan metode CAMEL dapat dilihat pada tabel dibawah ini:

\begin{tabular}{|c|c|c|c|c|}
\hline Uraian & Yang Dinilai & Rasio & Nilai Kredit & Bobot \\
\hline Capital & $\begin{array}{l}\text { Kecukupan } \\
\text { Modal }\end{array}$ & CAR & $\begin{array}{c}0 \mathrm{~s} / \mathrm{d} \\
\max 100\end{array}$ & $25 \%$ \\
\hline Assets & $\begin{array}{l}\text { Kualitas Aktiva } \\
\text { Produktif }\end{array}$ & $\begin{array}{l}\text { KAP } \\
\text { PPAP }\end{array}$ & $\begin{array}{l}\text { Max } 100 \\
\text { Max } 100\end{array}$ & $25 \%$ \\
\hline Management & $\begin{array}{l}\text { Kualitas } \\
\text { Manajemen }\end{array}$ & $\begin{array}{l}\text { Manajemen } \\
\text { Modal, Aktiva, } \\
\text { Umum, } \\
\text { Rentabilitas } \\
\text { dan Manajemen } \\
\text { Likuiditas }\end{array}$ & $\begin{array}{c}\text { Total } \\
\text { Max } 100\end{array}$ & $5 \%$ \\
\hline Earnings & $\begin{array}{l}\text { Kemampuan } \\
\text { Menghasilkan } \\
\text { Laba }\end{array}$ & $\begin{array}{l}\text { ROA } \\
\text { BOPO }\end{array}$ & $\begin{array}{l}\text { Max } 100 \\
\text { Max } 100\end{array}$ & $10 \%$ \\
\hline Liquidity & $\begin{array}{l}\text { Kemampuan } \\
\text { Menjamin } \\
\text { Likuiditas }\end{array}$ & $\begin{array}{l}\text { FDR } \\
\text { NCM-CA }\end{array}$ & $\begin{array}{l}\text { Max } 100 \\
\text { Max } 100\end{array}$ & $10 \%$ \\
\hline \multicolumn{5}{|c|}{ Sumber: Lukman (2009:143) } \\
\hline
\end{tabular}


Katerangan:

$\begin{aligned} \mathrm{CAR}= & \text { Capital Adequacy Ratio } \\ \mathrm{BDR}= & \text { Bad Deposit Ratio } \\ \mathrm{CAD}= & \text { Cadangan Aktiva yang } \\ & \text { Diklasifikasikan } \\ \mathrm{ROA}= & \text { Return on Assets } \\ \mathrm{BOPO}= & \text { Beban Operasional terhadap } \\ & \text { Pendapatan Operasional } \\ \mathrm{FDR}= & \text { Financing to Deposit Ratio }\end{aligned}$

NCM-CA $=$ Net Call Money to Current Asset

Berdasarkan observasi yang telah dilakukan, berikut data perkembangan PT Bank BCA Syariah, Tbk dari tahun 2013-2017:

Tabel 2. Rasio Keuangan PT Bank BCA Syariah Tbk Tahun 2013-2017

\begin{tabular}{|l|c|c|c|c|c|}
\hline \multicolumn{1}{|c|}{ RASIO } & $\mathbf{2 0 1 3}$ & $\mathbf{2 0 1 4}$ & $\mathbf{2 0 1 5}$ & $\mathbf{2 0 1 6}$ & $\mathbf{2 0 1 7}$ \\
\hline ROA & $1,0 \%$ & $0,8 \%$ & $1,0 \%$ & $1,1 \%$ & $1,2 \%$ \\
\hline BOPO & $90,2 \%$ & $92,9 \%$ & $92,5 \%$ & $92,2 \%$ & $87,2 \%$ \\
\hline FDR & $83,5 \%$ & $91,2 \%$ & $91,4 \%$ & $90,1 \%$ & $88,5 \%$ \\
\hline CAR & $22,4 \%$ & $29,6 \%$ & $34,3 \%$ & $36,7 \%$ & $29,4 \%$ \\
\hline \multicolumn{5}{|c|}{ Sumber: Laporan Tahunan PT. Bank BCA Syariah } \\
\hline
\end{tabular}

Tabel 3. Pertumbuhan Tahun Ke Tahun (Year on Year Growth)

\begin{tabular}{|l|c|c|c|c|}
\hline \multicolumn{1}{|c|}{ RASIO } & $\mathbf{2 0 1 3 - 2 0 1 4}$ & $\mathbf{2 0 1 4 - \mathbf { 2 0 1 5 }}$ & $\mathbf{2 0 1 5 - 2 0 1 6}$ & $\mathbf{2 0 1 6 - 2 0 1 7}$ \\
\hline ROA & $-0,2 \%$ & $0,2 \%$ & $0,1 \%$ & $0,1 \%$ \\
\hline BOPO & $2,7 \%$ & $-0,4 \%$ & $-0,3 \%$ & $-5 \%$ \\
\hline FDR & $7,7 \%$ & $0,2 \%$ & $-1,3 \%$ & $-1,6 \%$ \\
\hline CAR & $7,2 \%$ & $4,7 \%$ & $2,4 \%$ & $-7,3 \%$ \\
\hline \multicolumn{5}{|c|}{ Sumber: Laporan Tahunan PT. Bank BCA Syariah } \\
\hline
\end{tabular}

Berdasarkan tabel di atas mengindikasikan bahwa terdapat fluktuasi rasion ROA, BOPO, FDR, dan CAR Mengingat pentingnya penilaian tingkat kesehatan bank untuk menentukan kebijakan-kebijakan guna mempertahankan kelangsungan operasional perusahaan dalam menghadapi persaingan sesama jenis usaha. Banyak para pemegang rekening giro, deposito ataupun tabungan ingin mengetahui tingkat kesehatan suatu bank dimana pemegang saham menanamkan dananya. Hal ini semakin menambah pentingnya penilaian tingkat kesehatan bank untuk menentukan kebijakan-kebijakan guna mempertahankan kelangsungan operasional perusahaan dalam menghadapi persaingan sesama jenis usaha, maka penulis mengambil judul "Analisis Rasio Tingkat Kesehatan Bank Menggunakan Metode Camel Pada PT Bank BCA Syariah Tbk Jakarta Timur Tahun 2013-2017".

\section{METODE}

\section{Sifat Penelitian}

Penelitian bersifat deskriptif kuantitatif. penelitian deskriptif adalah penelitian yang menggambarkan atau menceritakan serta menguraikan bagaimana hasil dari perhitungan datadata finansial perusahaan dalam bentuk laporan keuangan. Sedangkan, penlitian kuantitatif adalah metode penelitian yang berlandaskan pada filsafat positivisme, digunakan untuk meneliti pada populasi atau sampel tertentu, pengumpulan data menggunakan instrument penelitian, analisis data bersifat kuantutatif atau statistik, dengan tujuan untuk menguji hipotesis yang telah ditetapkan (Sugiono, 2011: 8).

\section{Waktu dan Tempat Waktu}

Data yang diambil dalam penelitian ini dan penulisan skripsi ini adalah data-data yang terdapat dalam laporan keuangan PT Bank BCA Syariah Tbk. selama 5 periode terhitung mulai dari tahun 2013 sampai dengan 2017.

\section{Tempat}

Obyek penelitian yang dipilih penulis adalah PT. Bank BCA Syariah yang beralamatkan di Jl. Jatinegara Timur No. 72, Jakarta Timur, Telpon 021-8190072, 8505030, dan untuk memperoleh data dan informasi dalam penulisan skripsi ini, penulis telah melakukan penelitian pada Pusat Referensi Pasar Modal (PRPM) di gedung Bursa Efek Indonesia (BEI) yang berlokasi di Jl. Jend Sudirman kav. 52-53 Jakarta 12190, Phone: (021) 5150515, Fax: (021) 5152319

\section{Populasi dan Sampel Populasi}

Populasi menurut Sugiyono (2011:80) adalah wilayah generalisasi yang terdiri atas obyek atau subjek yang mempunya kualitas dan karakteristik tertentu yang ditetapkan oleh peneliti untuk dipelajari dan kemudian ditarik kesimpulannya. Populasi dapat berupa manusia, file-file atau dokumen yang dapat dipandang sebagai objek penelitian. Populasi dalam penelitian ini meliputi seluruh laporan keuangan PT Bank BCA Syariah 
periode tahun 2013 sampai dengan 2017.

\section{Sampel}

Sampel merupakan bagian dari jumah dan karakteristik yang diambil oleh populasi (Sugiyono,2011:81). Sampel dalam penelitian ini adalah laporan keuangan perusahaan berupa neraca dan laporan laba rugi PT. Bank BCA Syariah Tbk. periode 2013 sampai dengan 2017.

\section{Teknik Analisis Data}

Analisis data yang digunakan dalam penelitian ini adalah dengan menggunakan metode CAMEL, yang terdiri dari:

\section{Capital (Permodalan)}

Rasioyang digunakan dalam perhitungan ini adalah Capital Adequacy Ratio (CAR), yaitu merupakan perbandingan jumlah modal dengan jumlah Aktiva Tertimbang Menurut Ratio (ATMR) kemudian mencari nilai kreditnya, dengan formulasi sebagai berikut:

\footnotetext{
Rasio $C A R=\frac{\text { Total Modal }}{\text { Aktiva Terimbang Menurut Resiko }} \times 100 \%$

Nilai Kredit Rasio $C A R=\frac{C A R}{0,1}+1$
}

NK Faktor $C A R=$ NK Rasio $C A R x$ Bobot Rasio $C A R$

NK Faktor CAR memiliki bobot sebesar 25\% terhadap Nilai Bersih Rasio CAMEL

Tabel 4. Kriteria Penilaian Capital Adequacy Ratio (CAR)
\begin{tabular}{|c|c|}
\hline Rasio & Predikat \\
\hline CAR $>12 \%$ & Sangat Sehat \\
\hline $9 \leqslant$ CAR $<12 \%$ & Sehat \\
\hline $8 \% \leqslant$ CAR $9 \%$ & Cukup Sehat \\
\hline $6 \%<$ CAR $<8 \%$ & Kurang Sehat \\
\hline CAR $\leqslant 6 \%$ & Tidak Sehat \\
\hline \multicolumn{2}{|c|}{ Sumber: Surat Edaran Bank Indonesia No. 6/23/DPNP Tahun 2004} \\
\hline
\end{tabular}

\section{Asset (Aset)}

Perhitungan kualitas aktiva produktif menggunakan 2 rasio, yaitu rasio Kualitas Aktiva Produktif dan Rasio Pencadangan Penghapusan Aktiva Produktif.

1) Rasio Kualitas Aktiva Produktif (KAP) adalah perbandingan antara aktiva produktif yang diklasifikasikan (aktiva produktif yang sudah atau mengandung potensi menjadi tidak produktif) dengan total aktiva produktif. Aktiva produktif yang diklasifikasikan sebagai berikut:

a) $0 \%$ dari kredit yang lancar (L)

b) $25 \%$ dari kredit yang dalam perhatian khusus (DPK)

c) $50 \%$ dari kredit yang kurang lancar (KL)

d) $75 \%$ dari kredit yang diragukan (D)

e) $\quad 100 \%$ dari kredit macet $(\mathrm{M})$

KAP $=\frac{\text { Aktiva Produktif yang Diklasifikasikan }}{\text { Total Aktiva Produktif }} \times 100 \%$

NK Rasio KAP $=\frac{22,5 \%-\text { Rasio KAP }}{0,15 \%}$

NK Faktor KAP = NK Rasio KAP $x$ Bobot Rasio KAP

NK Faktor KAP memiliki bobot sebesar $25 \%$ terhadap Nilai Bersih Rasio CAMEL

\begin{tabular}{|c|c|}
\hline Tabel 5. Kriteria Penilaian Kualitas Aktiva Produk (KAP) \\
\hline Rasio & Predikat \\
\hline KAP $\leqslant 2$ & Sangat Sehat \\
\hline $2<$ KAP $\leqslant 3 \%$ & Sehat \\
\hline $3 \%<$ KAP $\leqslant 6 \%$ & Cukup Sehat \\
\hline $6 \%$ KAP $\leqslant 9 \%$ & Kurang Sehat \\
\hline KAP $>9 \%$ & Tidak Sehat \\
\hline \multicolumn{2}{|c|}{ Sumber: Surat Edaran Bank Indonesia No. 6/23/DPNP Tahun 2004} \\
\hline
\end{tabular}

2) Rasio penyisihan penghapusan aktiva produktif (PPAP) terhadap penyisihan penghapus aktiva produktif yang wajib dibentuk (PPAPWD)

\section{Rasio PPAP $=\frac{\text { PPAP }}{\text { PPAPWD }} \times 100 \%$}

Nilai Kredit dari Rasio PPAP dan NK Faktor PPAP dapat dihitung dengan cara:

NK Rasio PPAP $=\frac{\text { Rasio PPAP }}{1 \%}$

\section{NK Faktor PPAP $=$ NK Rasio PPAP $\times$ Bobot PPAP}

NK Faktor PPAP memiliki bobot sebesar 5\% terhadap Nilai Bersih Rasio CAMEL.

\section{Management}

Rasio Manajemen diukur berdasarkan pertanyaan dan pernyataan yang diajukan mengenai Manajemen Umum dan Manajemen Risiko. Manajemen Umum berisi pertanyaan dan pernyataan mengenai strategi atau sasaran, struktur, sistem sumber daya manusia, kepemimpinan dan budaya ker- 
ja sedangkan Manajemen Risiko berisi pertanyaan dan pernyataan mengenai risiko likuiditas, risiko pasar, risiko kredit, risiko operasional dan risiko hukum. Pertanyaan dan pernyataan yang diajukan mempunyai perbandingan $40 \%$ pertanyaan untuk Manajemen Umum dan $60 \%$ pertanyaan untuk Manajemen Risiko.

\begin{tabular}{|c|c|}
\hline \multicolumn{2}{|c|}{ Tabel 6. Kriteria Penilaian Net Profit Margin (NPM) } \\
\hline Rasio & Predikat \\
\hline $\mathrm{NPM} \geqslant 100 \%$ & Sangat Sehat \\
\hline $81 \% \leqslant \mathrm{NPM}<100 \%$ & Sehat \\
\hline $66 \% \leqslant \mathrm{NPM}<81 \%$ & Cukup Sehat \\
\hline $51 \% \leqslant \mathrm{NPM}<66 \%$ & Kurang Sehat \\
\hline $\mathrm{NPM}<51 \%$ & Tidak Sehat \\
\hline \multicolumn{2}{|c|}{ Sumber: Surat Edaran Bank Indonesia No. 6/23/DPNP Tahun 2004} \\
\hline
\end{tabular}

Namun dalam penelitian ini, analisis rasio manajemen tidak dilakukan karena adanya keterbatasan yang ada pada saat dilakukan nya penelitian. Pembatasan ini dilakukan mengingat bahwa untuk dapat melakukan penilaian tingkat kesehatan pada bank syariah dengan menggunakan metode CAMEL, tidak cukup hanya mendasarkan pada analisis yang tertuju hanya terhadap laporan keuangan yang dipublikasikan saja, tetapi juga data-data pendukung lainnya yang bersifat internal. Data yang berhubungan dengan aspek manajemen tidak dapat diperoleh hanya dengan menggandalkan dari data publikasi bank syariah tersebut, tetapi harus melalui survei kuisioner dan wawancara. Di Indonesia hanya Bank Indonesia dan bank yang bersangkutan saja yang dapat mengetahuinya

\section{Earning (Rentabilitas)}

Perhitungan prifitabilitas menggunakan 2 rasio, yaitu:

1) Rasio Return on Assets, yaitu perbandingan antara laba kotor sebelum pajak relatif terhadap total aset yang dimiliki oleh bank. Rasio dan nilai kreditnya dapat dihitung dengan formulasi sebagai berikut:

Rasio ROA $=\frac{\text { Laba Sebelum Pajak }}{\text { Total Aktiva }} \times 100 \%$

NK Rasio ROA $=\frac{\text { Rasio } \mathrm{ROA}}{\mathbf{0 , 0 1 5} \%}$

\section{NK Faktor ROA = NK Rasio ROA $x$ Bobot Rasio ROA}

NF Faktor ROA memiliki bobot sebesar $5 \%$ terhadap Nilai Bersih Rasio CAMEL. Dan untuk melihat tingat kesehatan bank dengan cara perhitungan menggunakan perhitungan return on asset dapat dilihat dalam tabel berikut:

\begin{tabular}{|c|c|}
\hline \multicolumn{2}{|c|}{ Tabel 7. Kriteria Penilaian Rasio Return on Assets (ROA) } \\
\hline Rasio & Predikat \\
\hline ROA $>15 \%$ & Sangat Sehat \\
\hline $1.25 \%<R O A \leqslant 1,5 \%$ & Sehat \\
\hline $0,5 \%<R O A \leqslant 1,25 \%$ & Cukup Sehat \\
\hline $0 \%<$ ROA $\leqslant 0,5 \%$ & Kurang Sehat \\
\hline ROA $\leqslant 0 \%$ & Tidak Sehat \\
\hline \multicolumn{2}{|c|}{ Sumber: Surat Edaran Bank Indonesia No. 6/23/DPNP Tahun 2004} \\
\hline
\end{tabular}

2) Rasio Biaya Operasional terhadap Pendapatan Operasional (BOPO). Dimana formulasi yang digunakan untuk penghitungan adalah:

Rasio BOPO $=\frac{\text { Beban Operasional }}{\text { Pendapatan Operasional }} \times 100 \%$

NK Rasio BOPO $=\frac{100 \%-\text { Rasio BOPO }}{0,08 \%}$

NK Faktor BOPO = NK BOPO $\times$ Bobot Rasio BOPO

NF Faktor BOPO memiliki bobot sebesar 5\% terhadap Nilai Bersih Rasio CAMEL

Tabel 8. Kriteria Penilaian Rasio Biaya Operasional
Terhadap Pendapatan Operasional (BOPO)

\section{Liquidity (Likuiditas)}

Perhitungan likuiditas menggunakan 2 rasio, yaitu:

1) Rasio Nett Call Money to Current Assets (NCM-CA)

Call money atau pinjaman singkat adalah penempatan dana jangka pendek pada bank lain (aktiva) atau penerimaan dana jangka pendek dari bank lain (pasiva). Singkatnya, call money adalah 
instrumen bank dalam mengatasi kekurangan atau kelebihan dana jangka pendek yang bersifat sementara. Net Call Money adalah kewajiban bersih yang dihitung dari selisih call money yang bersifat pasiva dengan call money yang bersifat aktiva.

\begin{tabular}{|c|c|}
\hline \multicolumn{2}{|c|}{ Tabel 9. Kriteria Penilaian Rasio Loan to Deposit Ratio (LDR) } \\
\hline Rasio & Predikat \\
\hline LDR $\leqslant 75 \%$ & Sangat Sehat \\
\hline $75 \%<L D R \leqslant 85 \%$ & Sehat \\
\hline $85 \%<L D R \leqslant 100 \%$ & Cukup Sehat \\
\hline $100 \%<\operatorname{LDR} \leqslant 120 \%$ & Kurang Sehat \\
\hline LDR $>120 \%$ & Tidak Sehat \\
\hline \multicolumn{2}{|c|}{ Sumber: Surat Edaran Bank Indonesia No. 6/23/DPNP Tahun 2004} \\
\hline
\end{tabular}

"NCM = Call Money Pasiva - Call Money Aktiva"

Nett Call Money to Current Assests adalah perbandingan dari besarnya Nett Call Money terhadap Aktiva lancar yang diformulasikan sebagai berikut:

NCM-CA $=\frac{\text { NCM }}{\text { Aktiva Lancar }} \times 100 \%$

Nilai kredit NCM-CA dapat dihitung dengan formulasi

NK NCM-CA $=\frac{100 \%-\text { Rasio NCM-CA }}{1 \%}$

\section{NK NCM-CA = NK NCM-CA $x$ Bobot NCM-CA}

NF Faktor NCM-CA memiliki bobot sebesar 5\% terhadap Nilai Bersih Rasio CAMEL.

2) FDR (Financing to Deposit Ratio)

FDR (Financing to Deposit Ratio), yaitu perbandingan antara pembiayaan yang disalurkan oleh bank terhadap dana pihak ketiga atau nasabah yang dihimpun oleh bank dan dipakai apabila sewaktuwaktu dibutuhkan oleh nasabah tesebut. FDR (Financing to Deposit Ratio) belum ada ketentuan dari OJK (Otoritas Jasa Keuangan) tetapi tingkat yang efektif adalah hingga $98 \%$.

$$
\boldsymbol{F D R}=\frac{\text { Pembiayaan }}{\text { Dana Pihak Ketiga }} \times \mathbf{1 0 0} \%
$$

Nilai Kredit dan Faktor FDR (Financing to Deposit Ratio) dihitung menggunakan rumus sebgai berikut:

$$
\text { NK FDR }=\frac{115 \%-\text { Rasio } F D R}{1 \%} \times 4
$$

NK Faktor $F D R=$ NK Rasio FDR $\times$ Bobot $F D R$

NF Faktor FDR (Financing to Deposit Ratio) memiliki bobot sebesar 5\% terhadap Nilai Bersih Rasio pada metode CAMEL

\begin{tabular}{|c|c|}
\hline Tabel 10. Kriteria Penilaian Financing to Deposito Ratio (FDR) \\
\hline Rasio & Predikat \\
\hline FDR $\leqslant 95 \%$ & Sangat Sehat \\
\hline $95<$ FDR $99 \%$ & Sehat \\
\hline $99 \%<$ FDR $102 \%$ & Cukup Sehat \\
\hline $102 \%<$ FDR $\leqslant 105 \%$ & Kurang Sehat \\
\hline FDR $>105 \%$ & Tidak Sehat \\
\hline \multicolumn{2}{|c|}{ Sumber: Surat Edaran Bank Indonesia No. 6/23/DPNP Tahun 2004 } \\
\hline
\end{tabular}

\section{HASIL dan PEMBAHASAN \\ Bank}

Menurut Kasmir (2008:2), Bank adalah lembaga keuangan yang kegiatan utamanya adalah menghimpun dana dari masyarakat dan menyalurkannya kembali dana tersebut ke masyarakat serta memberikan jasa bank lainnya. Berdasarkan UU No. 7 tahun 1992 tentang perbankan menyebutkan bahwa "Bank adalah badan usaha yang menghimpun dan dari masyarakat dalam bentuk simpanan dan menyalurkannya kepada masyarakat dalam rangka meningkatkan taraf hidup orang banyak".

\section{Bank Syariah}

Bank Syariah merupakan lembaga perbankan yang dijalankan dengan prinsip syariah. Dalam setiap aktivitas usahanya, bank syariah selalu menggunakan hukum-hukum Islam yang tercantum di dalam Al-Qur'an dan Hadist. Berbeda dengan bank konvensional yang mengandalkan sistem bunga, bank syariah lebih mengutamakan sistem bagi hasil, sistem sewa, dan sistem jual beli yang tidak menggunakan sistem riba sama sekali.

Menurut Scahik (2001: 3), pengertian bank syariah adalah suatu bentuk dari bank modern yang berlandaskan hukum-hukum agama Islam, 
yang dikembangkan pada abad pertengahan Islam dengan jalan menggunakan konsep bagi hasil dan bagi resiko sebagai sistem utama dan menghapuskan sistem keuangan yang dilandasi dengan anggapan kepastian keuntungan yang telah ditentukan sebelumnya.

Prinsip bank syariah adalah aturan perjanjian berdasarkan hukum Islam antara bank dan pihak lain untuk penyimpanan dana dan/atau pembiayaan kegiatan usaha, atau kegiatan lainnya yang sesuai dengan syariah, selain itu prinsip bank syariah juga kadang menguntungkan bagi nasabah yang percaya akan produk-produk pada bank syariah. Prinsip utama operasional bank yang berdasarkan prinsip syariah adalah hukum Islam yang bersumber dari $\mathrm{Al}$ Qur'an dan $\mathrm{Al}$ Hadits. Kegiatan operasional bank harus memperhatikan perintah dan larangan dalam Al Qur'an dan Sunnah Rosul Muhammad Shallallahu Alaihi Wasallam. Larangan utama berkaitan dengan kegiatan bank yang dapat diklasifikasikan sebagai Riba. Dalam menjalankan kegiatan operasionalnya, bank yang menggunakan prinsip syariah tidak menggunakan sistem bunga dalam menentukan imbalan atas dana yang digunakan atau dititipkan oleh suatu pihak. Penentuan imbalan terhadap dana yang dipinjamkan maupun dana yang disimpan di bank berdasarkan pada prinsip bagi hasil sesuai dengan hukum Islam. Ditinjau dari sisi pelayanan terhadap masyarakat dan pemasaran, adanya bank atas dasar prinsip syariah merupakan usaha untuk melayani dan mendayagunakan segmen pasar perbankan yang tidak setuju atau tidak menyukai sistem bunga.

\section{Kesehatan Bank}

Menurut Surat Edaran Bank Indonesia Nomor: 6/23/DPNP tanggal 31 Mei 2004, penilaian tingkat kesehatan bank merupakan penilaian kualitatif atas berbagai aspek yang berpengaruh terhadap kondisi atau kinerja suatu bank melalui penilaian aspek permodalan, kualitas aset, manajemen, rentabilitas, likuiditas dan sensitivitas terhadap resiko pasar. Penilaian terhadap faktor-faktor tersebut dilakukan melalui penilaian kuantitatif dan kualitatif setelah mempertimbangkan unsur judgement yang didasarkan atas meterialitas dan signifikansi dari faktor-faktor penilaian serta pengaruh dari faktor lainnya seperti kondisi industri perbankan dan perekonomian nasional.

Penggolongan tingkat kesehatan bank dibagi dalam empat kategori yaitu : sehat, cukup sehat, kurang sehat dan tidak sehat, namun sistem pemberian nilai dalam menetapkan tingkat kesehatan bank didasarkan pada "reward system" dengan nilai kredit antara 0 sampai dengan 100, yakni sebagai berikut:

\begin{tabular}{|c|c|}
\hline Tabel 11. Nilai Kredit Penggolongan Tingkat Kesehatan Bank \\
\hline Nilai Kredit & Predikat \\
\hline $81-100$ & Sehat \\
\hline $66-<81$ & Cukup Sehat \\
\hline $51-<66$ & Kurang Sehat \\
\hline $0<51$ & Tidak Sehat \\
\hline \multicolumn{2}{|c|}{ Sumber: Surat Edaran Bank Indonesia No. 6/23/DPNP Tahun 2004 } \\
\hline
\end{tabular}

Penilaian kesehatan bank dilakukan setiap tahun, apakah ada peningkatan atau penurunan. Bagi bank yang kesehatannya terus meningkat tak jadi masalah, karena itulah yang diharapkan dan suatu upaya untuk mempertahankan kesehatannya. Akan tetapi bagi bank yang terus menerus tidak sehat, mungkin harus mendapatkan pengarahan atau sanksi dari Bank Indonesia sebagai pengawas dan pembina bank-bank.

\section{Metode Camel}

Menurut Kasmir (2008: 185-186), salah satu alat untuk mengukur kesehatan bank adalah dengan analisis CAMEL. Unsur-unsur penilaian dalam analisis CAMEL adalah sebagai berikut:

\section{Capital}

Penilaian didasarkan kepada permodalan yang dimiliki oleh salah satu Bank. Salah satu penilaian adalah dengan metode CAR (Capital Adequacy Rasio) yaitu dengan cara membandingkan modal terhadap aktiva tertimbang menurut resiko (ATMR).

\section{Assets}

Penilaian didasarkan kepada kualitas aktiva yang dimiliki Bank. Berikut Rasio yang diukur ada 2 macam yaitu sebagai berikut :

1) Rasio Kualitas Aktiva Produktif (KAP).

2) Rasio Penyisihan Penghapusan Aktiva 
Produktif (PPAP).

\section{Management}

Penilaian didasarkan kepada manajemen permodalan, manajemen aktiva, manajemen rentabilitas, manajemen likuiditas dan manajemen umum.

\section{Earnings}

Penilaian didasarkan kepada rentabilitas suatu bank yaitu melihat kemampuan suatu bank dalam menciptakan laba. Penilaian dalam unsur ini didasarkan kepada 2 macam yaitu :

1) Rasio laba terhadap total aset (Return on Assets).

2) Rasio Beban Oprasional Terhadap Pendapatan Oprasional (BOPO)

\section{Liquidity}

Yaitu untuk menilai likuiditas bank. Penilaian likuiditas bank didasarkan kepada 2 macam rasio yaitu :

1) Rasio Net Call Money to Current Assets (NCM-CA), atau rasio kewajiban bersih call money terhadap aktiva lancar dan yang termasuk aktiva lancar adalah Kas, Giro pada BI, Sertifikat Bank Indonesia (SBI) dan Surat Berharga Pasar Uang (SBPU) yang sudah diberikan oleh bank lain.

20 Rasio Financing to Deposit Ratio, yaitu perbandingan antara kredit yang disalurkan bank terhadap dana pihak ketiga yang dihimpun oleh bank.

\section{Analisis Kinerja Keuangan \\ Dengan Metode CAMEL}

\section{Capital (Permodalan)}

Rasio permodalan diukur dengan membandingkan antara Modal Sendiri terhadap Aktiva Tertimbang Menurut Risiko (ATMR), Sehingga rasio (Capital Adequacy Ratio) CAR PT. Bank BCA Syariah Tbk. selama tahun 2013 sampai dengan 2017 adalah sebagai berikut:
Tabel 12. Perhitungan Capital Asset Ratio (CAR) (dalam Miliar Rupiah)

\begin{tabular}{|c|c|c|c|}
\hline Tahun & Total Modal & ATMR & CAR \\
\hline 2013 & 306.000 & 2.041 .419 & $14,98 \%$ \\
\hline 2014 & 618.600 & 2.157 .000 & $28,67 \%$ \\
\hline 2015 & 1.042 .300 & 3.117 .800 & $34,43 \%$ \\
\hline 2016 & 1.099 .300 & 4.995 .600 & $22,00 \%$ \\
\hline 2017 & 1.136 .100 & 3.961 .200 & $28,68 \%$ \\
\hline \multicolumn{4}{|c}{ Sumber: Laporan Keuangan PT. Bank BCA Syariah Tbk. (Data Diolah) } \\
\hline \multicolumn{4}{|c}{}
\end{tabular}

Rasio CAR pada PT. Bank BCA Syariah Tbk. per 31 Desember 2013 sebesar 14,98\%, tahun 2014 sebesar 28,67\%, tahun 2015 sebesar 34,43\%, tahun 2016 sebesar 22,00\%, tahun 2017 sebesar 28,68\%.

Pencapaian CAR periode tahun 2013 sampai dengan 2017 yang selalu berada diatas angka $8 \%$ adalah hal yang positif atau sangat bagus bagi perkembangan bank, karena menurut ketentuan dari Bank Indonesia yang menyatakan bahwa bank yang sehat memiliki rasio CAR setidaknya $8 \%$. Semakin besar rasio CAR yang dimiliki oleh bank maka akan semakin baik hal ini dikarenakan bank mampu menyediakan modal dalam jumlah yang besar bagi pihak nasabah demi mensejahterakan kemajuan dari bank itu sendiri.

Dari hasil perhitungan nilai rasio CAR, maka selanjutnya adalah akan dilakukan perhitungan analisis Nilai Kredit Rasio CAR pada PT. Bank BCA Syariah Tbk. tahun 2013-2017.

\begin{tabular}{|c|c|c|c|c|c|}
\hline \multicolumn{6}{|c|}{ Tabel 13. Nilai Kredit Rasio CAR } \\
\hline Tahun & CAR & Nilai Kredit & Nilai Maksimum & Bobot & Nilai Faktor \\
\hline 2013 & $14,98 \%$ & 150,8 & 100 & $25 \%$ & 25 \\
\hline 2014 & $28,67 \%$ & 287,7 & 100 & $25 \%$ & 25 \\
\hline 2015 & $34,43 \%$ & 345,3 & 100 & $25 \%$ & 25 \\
\hline 2016 & $22,00 \%$ & 221 & 100 & $25 \%$ & 25 \\
\hline 2017 & $28,68 \%$ & 287,1 & 100 & $25 \%$ & 25 \\
\hline \multicolumn{6}{|c|}{ Sumber: Laporan Keuangan PT. Bank BCA Syariah Tbk. (Data Diolah) } \\
\hline
\end{tabular}

Nilai Kredit Rasio CAR PT. Bank BCA Syariah Tbk. per 31 Desember 2013 sebesar 150,8, tahun 2014 sebesar 287,7, tahun 2015 sebesar 345,3, tahun 2016 sebesar 221, dan tahun 2017 sebesar 287,1. Oleh karena nilai kredit dibatasi maksimum 100 maka nilai kredit rasio CAR pada tahun 2013 hingga 2017 diatas diakui sebagai 100. 


\section{Assets (Aset)}

Aktiva Produktif PT. Bank BCA Syariah Tbk. Dapat dilihat dalam tabel berikut:

\begin{tabular}{|c|c|c|c|c|c|}
\hline \multicolumn{6}{|c|}{$\begin{array}{l}\text { Tabel 14. Aktiva Produktif PT. Bank BCA Syariah Tbk. } \\
\text { (dalam Miliar Rupiah) }\end{array}$} \\
\hline Tahun & $\begin{array}{l}\text { Lancar } \\
\text { (L) }\end{array}$ & $\begin{array}{l}\text { Dalam Perhatian } \\
\text { Khusus (DPK) }\end{array}$ & $\begin{array}{l}\text { Kurang } \\
\text { Lancar } \\
\text { (KL) }\end{array}$ & $\begin{array}{l}\text { Diragukan } \\
\text { (D) }\end{array}$ & $\begin{array}{l}\text { Macet } \\
\text { (M) }\end{array}$ \\
\hline 2013 & 1.401 .600 & 18.600 & 0 & 500 & 900 \\
\hline 2014 & 2.081 .100 & 48.600 & 0 & 300 & 2.200 \\
\hline 2015 & 2.895 .800 & 58.800 & 11.600 & 400 & 8.900 \\
\hline 2016 & 3.409 .900 & 35.500 & 9.600 & 6.500 & 1.400 \\
\hline 2017 & 4.131 .700 & 46.000 & 1.400 & 1.400 & 10.600 \\
\hline
\end{tabular}

\begin{tabular}{|c|c|c|c|c|c|c|}
\hline \multicolumn{7}{|c|}{$\begin{array}{l}\text { Tabel 15. Aktiva Produktif Yang Diklasifikasikan } \\
\text { PT. Bank BCA Syariah Tbk (dalam Jutaan Rupiah) }\end{array}$} \\
\hline Tahun & $\begin{array}{c}L \\
10 \%)\end{array}$ & DPK $(25 \%)$ & KL $(50 \%)$ & $D(75 \%)$ & $\begin{array}{c}M \\
(100 \%)\end{array}$ & Total \\
\hline 2013 & - & 4.650 & 0 & 350 & 900 & 5.900 \\
\hline 2014 & - & 12.150 & 0 & 210 & 2.200 & 14.560 \\
\hline 2015 & - & 14.700 & 5.800 & 280 & 8.900 & 29.680 \\
\hline 2016 & - & 8.875 & 4.800 & 4.550 & 1.400 & 19.625 \\
\hline 2017 & - & 11.500 & 700 & 980 & 10.600 & 23.780 \\
\hline
\end{tabular}

Kualitas Aktiva Produktif (KAP) pada Bank BCA Syariah tahun 2013 sampai dengan2017:

Tabel 16. Perhitungan Rasio Kualitas Aktiva Produktif (dalam Miliar Rupiah)

\begin{tabular}{|c|c|c|c|}
\hline Tahun & Aktiva Produktif & AP Diklasifikasikan & Rasio KAP \\
\hline 2013 & 1.421 .600 & 5.900 & $0,41 \%$ \\
\hline 2014 & 2.132 .200 & 14.500 & $0,68 \%$ \\
\hline 2015 & 2.975 .500 & 29.680 & $0,99 \%$ \\
\hline 2016 & 3.462 .900 & 19.625 & $0,56 \%$ \\
\hline 2017 & 4.191 .000 & 23.780 & $0,56 \%$ \\
\hline \multicolumn{4}{|c}{ Sumber: Laporan Keuangan PT. Bank BCA Syariah Tbk. (Data Diolah) } \\
\hline
\end{tabular}

Rasio KAP pada PT. Bank BCA Syariah Tbk. per 31 Desember 2013 sebesar 0,41\%, tahun 2014 sebesar 0,68\%, tahun 2015 sebesar 0,99\%, tahun 2016 sebesar 0,56\% dan tahun 2017 sebesar $0,56 \%$. Setelah melakukan perhitungan nilai rasio KAP, maka selanjutnya adalah melakukan analisis Nilai Kredit Rasio KAP pada PT. Bank BCA Syariah Tbk. tahun 2013 sampai dengan 2017.

\begin{tabular}{|c|c|c|c|c|c|}
\hline \multicolumn{6}{|c|}{ Tabel 17. Nilai Kredit Faktor KAP } \\
\hline Tahun & Rasio KAP & NK Rasio KAP & $\begin{array}{c}\text { NK } \\
\text { Maksimum }\end{array}$ & Bobot & NK Faktor \\
\hline 2013 & $0,41 \%$ & 147,2 & 100,00 & $25 \%$ & 25 \\
\hline 2014 & $0,68 \%$ & 145,4 & 100,00 & $25 \%$ & 25 \\
\hline 2015 & $0,99 \%$ & 143,4 & 100,00 & $25 \%$ & 25 \\
\hline 2016 & $0,56 \%$ & 146,2 & 100,00 & $25 \%$ & 25 \\
\hline 2017 & $0,56 \%$ & 146,2 & 100,00 & $25 \%$ & 25 \\
\hline
\end{tabular}

Nilai Kredit rasio KAP pada PT. Bank BCA Syariah Tbk. per 31 Desember 2013 sebesar 147,2, tahun 2014 sebesar 145,4, tahun 2015 sebesar 143,3, tahun 2014 sebesar 146,2, dan tahun 2015 sebesar 146,2. Oleh karena nilai kredit dibatasi maksimum 100 maka nilai kredit rasio KAP pada tahun 2013 hingga 2017 diatas diakui sebagai 100 .

Perolehan nilai maksimum pada nilai kredit rasio KAP dalam kurun waktu 2013 sampai dengan 2017 menunjukan kinerja yang positif, karena semakin kecil rasio Kualitas Aktiva Produktif (KAP) berarti aktiva produktif yang bermasalah (atau berpotensi bermasalah) pada bank tersebut relatif kecil bahkan relatif tidak ada dan hal tesebut akan semakin baik bagi perkembangan bank dari tahun ke tahun.

Penyisihan penghapusan aktiva produktif (PPAP) adalah cadangan yang wajib dibentuk sebesar persentase tertentu dari nominal berdasarkan penggolongan kualitas aktiva produktif sebagaimana ditetapkan dalam Surat Keputusan Direksi Bank Indonesia No.31/147/KEP/DIR tanggal 12 November 1998 tentang kualitas aktiva produktif. Rasio ini membandingkan antara:

a. Penyisihan Penghapusan Aktiva Produktif Wajib Dibentuk (PPAWD) sesuai dengan peraturan yang ditetapkan Bank Indonesia, terhadap;

b. Penyisihan Penghapusan Aktiva Produktif (PPAP) yang telah dibentuk oleh Bank

Berikut ini adalah hasil analisis Penyisihan Penghapusan Aktiva Produktif (PPAP) pada PT. Bank BCA Syariah Tbk. tahun 2013 sampai dengan 2017: 


Tabel 18. Perhitungan Penyisihan Penghapusan Aktiva Produktif (PPAP)
(dalam Jutaan Rupiah)
\begin{tabular}{|c|c|c|c|}
\hline Tahun & $\begin{array}{c}\text { Penyisihan Penghapusan } \\
\text { Aktiva Produktif Wajib } \\
\text { Dibentuk (PPAPWD) }\end{array}$ & $\begin{array}{c}\text { Penyisihan Penghapusan } \\
\text { Aktiva Produktif } \\
\text { (PPAP) }\end{array}$ & $\begin{array}{c}\text { Rasio } \\
\text { KAP }\end{array}$ \\
\hline 2013 & 131.169 & 131.206 & $102 \%$ \\
\hline 2014 & 129.456 & 130.050 & $104 \%$ \\
\hline 2015 & 194.576 & 197.922 & $101,7 \%$ \\
\hline 2016 & 235.678 & 206.117 & $87,4 \%$ \\
\hline 2017 & 355.168 & 383.964 & $108,1 \%$ \\
\hline & Sumber: Laporan Keuangan PT. Bank BCA Syariah Tbk. (Data Diolah) \\
\hline
\end{tabular}

Rasio (Penyisihan Penghapusan Aktiva Produktif) PPAP pada PT. Bank BCA Syariah Tbk. per 31 Desember 2013 sebesar 102\%, tahun 2014 sebesar 104\%, tahun 2015 sebesar $101,7 \%$, tahun 2016 sebesar 87.4\%, tahun 2017 sebesar 108,1\%. Hal ini menunjukkan dari tahun 2013 hingga 2017 rasio PPAP Bank BCA Syariah mengalami fluktuasi. Namun adanya kenaikan rasio PPAP ini disebabkan oleh perbaikan pada aktiva produktif, sehingga PPAP yang dibentuk cukup untuk mengantisipasi adanya kenaikan maupun penurunan kualitas aktiva produktif. Demikian pula sebaliknya, penurunan rasio PPAP ini disebabkan oleh penurunan pada aktiva produktif sehingga PPAP yang dibentuk kurang untuk mengantisipasi adanya kenaikan maupun penurunan kualitas aktiva produktif.

Setelah melakukan perhitungan nilai rasio PPAP, maka selanjutnya adalah melakukan analisis Nilai Kredit Rasio PPAP. Nilai Kredit Rasio PPAP pada PT. Bank BCA Syariah Tbk. tahun 2013 sampai dengan 2017:

\begin{tabular}{l}
\hline \multicolumn{7}{|c|}{ Tabel 19. Nilai Kredit Faktor PPAP } \\
\begin{tabular}{|c|c|c|c|c|c|}
\hline Tahun & Rasio PPAP & NK PPAP & NK Maksimum & Bobot & NK Faktor \\
\hline 2013 & $102 \%$ & 102 & 100,00 & $5 \%$ & 5 \\
\hline 2014 & $104 \%$ & 104 & 100,00 & $5 \%$ & 5 \\
\hline 2015 & $101,7 \%$ & 101,7 & 100,00 & $5 \%$ & 5 \\
\hline 2016 & $87,4 \%$ & 87,4 & 87,4 & $5 \%$ & 4,37 \\
\hline 2017 & $108,1 \%$ & 108,1 & 100,00 & $5 \%$ & 5 \\
\hline \multicolumn{7}{|c|}{ Sumber: Laporan Keuangan PT. Bank BCA Syariah Tbk. (Data Diolah) } \\
\hline
\end{tabular}
\end{tabular}

Nilai Kredit Rasio PPAP PT. Bank BCA Syariah Tbk. per 31 Desember 2013 sebesar 102, tahun 2014 sebesar 104, tahun 2015 sebesar 101,7, tahun 2016 sebesar 87,4, dan tahun 2017 sebesar 108,1. Oleh karena nilai kredit dibatasi maksimum 100 maka nilai kredit PPAP pada tahun 2013,2014,2015, dan 2017 diatas diakui sebagai 100, sedangkan nilai kredit PPAP pada tahun 2016 tetap diakui 87,4 karena masih dibawah nilai maksimum. Semakin besar rasio PPAP yang dimiliki oleh bank maka akan semakin baik yang berarti bank melakukan persiapan yang benar dalam mengantisipasi penghapusan kredit macet.

\section{Management}

Rasio Manajemen diukur berdasarkan pertanyaan dan pernyataan yang diajukan mengenai Manajemen Umum dan Manajemen Risiko.

Manajemen Umum berisi pertanyaan dan pernyataan mengenai strategi atau sasaran, struktur, sistem sumber daya manusia, kepemimpinan dan budaya kerja sedangkan Manajemen Risiko berisi pertanyaan dan pernyataan mengenai risiko likuiditas, risiko pasar, risiko kredit, risiko operasional dan risiko hukum. Pertanyaan dan pernyataan yang diajukan mempunyai perbandingan 40\% pertanyaan untuk Manajemen Umum dan $60 \%$ pertanyaan untuk Manajemen Risiko.

Tingkat kinerja manajemen dapat diukur dengan penghitungan Net Profit Margin (NPM). NPM merupakan rasio keuangan yang mengukur kemampuan bank dalam menghasilkan net income dari kegiatan operasional pokok bank. Rasio ini menggambarkan tingkat keuntungan (laba) yang diperoleh bank dibandingkan dengan pendapatan yang diterima dari kegiatan operasionalnya (Payamta dan Machfoedz, 1999:87). NPM ini berfungsi untuk mengukur tingkat kembalian keuntungan bersih terhadap penjualan bersihnya.

Namun dalam penelitian ini, analisis rasio manajemen tidak dilakukan karena adanya keterbatasan yang ada pada saat dilakukannya penelitian. Pembatasan ini dilakukan mengingat bahwa untuk dapat melakukan penilaian tingkat kesehatan pada bank syariah dengan menggunakan metode CAMEL, tidak cukup hanya mendasarkan 
pada analisis yang tertuju hanya terhadap laporan keuangan yang dipublikasikan saja, tetapi juga data-data pendukung lainnya yang bersifat internal. Data yang berhubungan dengan aspek manajemen tidak dapat diperoleh hanya dengan menggandalkan dari data publikasi bank syariah tersebut, tetapi harus melalui survey kuisioner dan wawancara. Di Indonesia hanya Bank Indonesia dan bank yang bersangkutan saja yang dapat mengetahuinya.

\section{Earnings (Rentabilitas)}

Berikut ini adalah hasil analisis (Return on Assets) ROA pada PT. Bank BCA Syariah Tbk. tahun 2013 sampai dengan 2017:

Tabel 20. Perhitungan Return on Assets (ROA) (dalam Miliar Rupiah)
\begin{tabular}{|c|c|c|c|}
\hline Tahun & Laba & Total Aktiva & Rasio ROA \\
\hline 2013 & 16.800 & 2.041 .400 & $0,82 \%$ \\
\hline 2014 & 17.500 & 2.994 .400 & $0,58 \%$ \\
\hline 2015 & 31.900 & 4.393 .600 & $0,72 \%$ \\
\hline 2016 & 49.200 & 4.995 .600 & $0,98 \%$ \\
\hline 2017 & 62.200 & 5.961 .200 & $1,04 \%$ \\
\hline \multicolumn{4}{|c|}{ Sumber: Laporan Keuangan PT. Bank BCA Syariah Tbk. (Data Diolah) } \\
\hline
\end{tabular}

Rasio (Return on Asset) ROA pada PT. Bank BCA Syariah Tbk. per 31 Desember 2013 sebesar 0,82\%, tahun 2014 sebesar 0,58\%, tahun 2015 sebesar 0,72\%, tahun 2016 sebesar 0,98\% dan tahun 2015 sebesar 1,04\%.

PT. Bank BCA Syariah Tbk. mencatatkan pencapaian (Return On Asset) ROA yang baik pada periode tahun 2013 sampai dengan tahun 2017, dimana sesuai dengan ketetapan yang telah dibuat oleh Bank Indonesia, bahwa (Return on Asset) ROA yang ideal (kategori sehat) pada suatu bank adalah paling sedikit $1,22 \%$ dikarenakan hal tersebut akan lebih mempermudah proses perkembangan yang baik bagi bank yang terus berjalan dari tahun ke tahun.

Setelah melakukan perhitungan nilai rasio (Return on Asset) ROA pada PT Bank BCA Syariah Tbk, maka selanjutnya adalah akan dilakukan perhitungan analisis Nilai Kredit Rasio (Return on Asset) ROA pada PT. Bank BCA Syariah Tbk. tahun 2013-2017.

\begin{tabular}{|c|c|c|c|c|}
\hline \multicolumn{5}{|c|}{ Tabel 21. Nilai Kredit Faktor ROA } \\
\hline Tahun & Rasio ROA & NK ROA & Bobot & NK Faktor \\
\hline 2013 & $0,82 \%$ & 54,66 & $5 \%$ & 2,73 \\
\hline 2014 & $0,58 \%$ & 38,66 & $5 \%$ & 1,93 \\
\hline 2015 & $0,72 \%$ & 48 & $5 \%$ & 2,4 \\
\hline 2016 & $0,98 \%$ & 65,33 & $5 \%$ & 3,27 \\
\hline 2017 & $1,04 \%$ & 69,33 & $5 \%$ & 3,47 \\
\hline \multicolumn{6}{|c|}{ Sumber: Laporan Keuangan PT. Bank BCA Syariah Tbk. (Data Diolah) } \\
\hline
\end{tabular}

Nilai Kredit Rasio ROA pada PT. Bank BCA Syariah Tbk. per 31 Desember 2013 sebesar 54,66, tahun 2014 sebesar 38,66, tahun 2015 sebesar 48, tahun 2016 sebesar 65,33, dan tahun 2017 sebesar 69,33. Sedangkan hasil analisis Beban Operasional terhadap Pendapatan Operasional (BOPO) pada PT. Bank BCA Syariah Tbk. tahun 2013-2017:

Tabel 22. Rasio Beban Operasional terhadap
Pendapatan Operasional (BOPO) (dalam Jutaan Rupiah)
\begin{tabular}{|c|c|c|c|}
\hline Tahun & Beban Operasional & Pendapatan Operasional & Rasio BOPO \\
\hline 2013 & 63.700 & 80.600 & $79,03 \%$ \\
\hline 2014 & 82.100 & 94.500 & $86,88 \%$ \\
\hline 2015 & 107.800 & 163.100 & $66,10 \%$ \\
\hline 2016 & 126.400 & 204.200 & $61,90 \%$ \\
\hline 2017 & 146.600 & 226.600 & $64,70 \%$ \\
\hline \multicolumn{4}{|c|}{ Sumber: Laporan Keuangan PT. Bank BCA Syariah Tbk. (Data Diolah) } \\
\hline
\end{tabular}

Rasio BOPO pada PT. Bank BCA Syariah Tbk. per 31 Desember 2013 sebesar 79,03\%, tahun 2014 sebesar 86,88\%, tahun 2015 sebesar 66,10\%, tahun 2016 sebesar 61,90\% dan tahun 2017 sebesar $64,70 \%$. Terjadinya penurunan rasio BOPO ini menunjukkan semakin baiknya tingkat efisiensi yang dijalankan oleh bank bersangkutan. Semakin kecil rasio BOPO suatu bank berarti usaha yang dijalankan oleh bank tersebut semakin efisien karena dengan biaya yang dikeluarkan mampu mendapatkan penghasilan yang memadai.

Setelah melakukan perhitungan nilai rasio BOPO (Beban Oprasional Pendapatan Operasional), maka selanjutnya adalah melakukan analisis nilai kredit Rasio BOPO (Beban Oprasional Pendapatan Oprasional) pada PT. Bank BCA Syariah Tbk. tahun 2013 sampai dengan 2017. 


\begin{tabular}{l}
\hline \multicolumn{7}{c}{ Tabel 23. Nilai Kredit Faktor BOPO } \\
\begin{tabular}{|c|c|c|c|c|c|}
\hline Tahun & Rasio BOPO & NK BOPO & NK Maksimum & Bobot & NK Faktor \\
\hline 2013 & $79,03 \%$ & 258,75 & 100,00 & $5 \%$ & 5 \\
\hline 2014 & $86,88 \%$ & 164 & 100,00 & $5 \%$ & 5 \\
\hline 2015 & $66,10 \%$ & 423,75 & 100,00 & $5 \%$ & 5 \\
\hline 2016 & $61,90 \%$ & 476,25 & 100,00 & $5 \%$ & 5 \\
\hline 2017 & $64,70 \%$ & 441,25 & 100,00 & $5 \%$ & 5 \\
\hline \multicolumn{7}{|c|}{ Sumber: Laporan Keuangan PT. Bank BCA Syariah Tbk. (Data Diolah) } \\
\hline
\end{tabular}
\end{tabular}

Nilai Kredit Rasio BOPO Bank BCA Syariah per 31 Desember 2013 sebesar 258,75, tahun 2014 sebesar 164, tahun 2015 sebesar 423,75, tahun 2016 sebesar 476,25, dan tahun 2017 sebesar 441,25 . Oleh karena nilai kredit dibatasi maksimum 100 maka nilai rasio BOPO pada tahun 2013-2017 diatas diakui sebagai 100.

\section{Liquidity (Likuiditas)}

Berikut ini adalah hasil analisis Net Call Money to Current Asset pada PT. Bank BCA Syariah Tbk. tahun 2013-2017:

\begin{tabular}{l}
\hline Tabel 24. Perhitungan Net Call Money to Current Assets (NCM-CA) \\
(dalam Miliar Rupiah) \\
\begin{tabular}{|c|c|c|c|c|c|}
\hline Tahun & $\begin{array}{c}\text { Call Money } \\
\text { Pasiva }\end{array}$ & $\begin{array}{c}\text { Call Money } \\
\text { Aktiva }\end{array}$ & $\begin{array}{c}\text { Nett Call } \\
\text { Money }\end{array}$ & $\begin{array}{c}\text { Aktiva } \\
\text { Lancar }\end{array}$ & $\begin{array}{c}\text { Rasio } \\
\text { NCM-CA }\end{array}$ \\
\hline 2013 & 979.719 & 282.341 & 679.378 & 5.031 .389 & $13,8 \%$ \\
\hline 2014 & 212.566 & 774.847 & -562.281 & 2.128 .021 & $-26.4 \%$ \\
\hline 2015 & 1.551 .742 & 379.753 & 1.171 .989 & 2.982 .698 & $39,2 \%$ \\
\hline 2016 & 877.445 & 412.351 & 465.094 & 3.888 .745 & $11,9 \%$ \\
\hline 2017 & 540.272 & 153.226 & 387.046 & 5.031 .389 & $7,6 \%$ \\
\hline \multicolumn{7}{|c|}{ Sumber: Laporan Keuangan PT. Bank BCA Syariah Tbk. (Data Diolah) } \\
\hline
\end{tabular}
\end{tabular}

Rasio NCM-CA pada PT. Bank BCA Syariah Tbk. per 31 Desember 2013 sebesar $13,8 \%$, tahun 2014 sebesar $-26,4 \%$, tahun 2015 sebesar 39,2\%, tahun 2016 sebesar $12,0 \%$ dan tahun 2017 sebesar 7,6\%. Hal ini menunjukkan dari tahun 2013 hingga 2017 rasio NCM-CA PT. Bank BCA Syariah Tbk. mengalami fluktuasi.

Setelah melakukan perhitungan nilai rasio NCM-CA, maka selanjutnya adalah melakukan prhitungsn analisis nilai kredit NCM-CA pada Bank BCA Syariah tahun 2013-2017.

\begin{tabular}{|c|c|c|c|c|}
\hline \multicolumn{5}{|c|}{ Tabel 25. Nilai Kredit Faktor NCM-CA } \\
\hline Tahun & Rasio NCM-CA & NK NCM-CA & Bobot & NK Faktor \\
\hline 2013 & $13,8 \%$ & 86,2 & $5 \%$ & 4,31 \\
\hline 2014 & $-26,4 \%$ & 126,4 & $5 \%$ & 5.00 \\
\hline 2015 & $39,3 \%$ & 60,8 & $5 \%$ & 3,40 \\
\hline 2016 & $12,0 \%$ & 88,1 & $5 \%$ & 4,40 \\
\hline 2017 & $7,7 \%$ & 92,4 & $5 \%$ & 4,62 \\
\hline \multicolumn{5}{|c|}{ Sumber: Laporan Keuangan PT. Bank BCA Syariah Tbk. (Data Diolah) } \\
\hline
\end{tabular}

Nilai Kredit NCM-CA PT. Bank BCA Syariah Tbk. per 31 Desember 2013 sebesar 86,2, tahun 2014 sebesar 126,4, tahun 2015 sebesar 60,8, tahun 2016 sebesar 88,1 dan tahun 2017 sebesar 92,4. Pada neraca tahun 2014, karena nilai kredit melampui nilai maksimum maka nilai kredit yang yang dihitung diakui 100. Hasil FDR pada PT. Bank BCA Syariah Tbk. tahun 2013-2017:

Tabel 26. Perhitungan Financing to Deposit Ratio (FDR) (dalam Miliar Rupiah)

\begin{tabular}{|c|c|c|c|}
\hline Tahun & Pembiayaan & DPK & Rasio FDR \\
\hline 2013 & 1.421 .600 & 1.703 .000 & $83,4 \%$ \\
\hline 2014 & 2.132 .200 & 2.338 .700 & $91,1 \%$ \\
\hline 2015 & 2.975 .500 & 3.255 .200 & $91,4 \%$ \\
\hline 2016 & 3.462 .800 & 3.842 .300 & $90,1 \%$ \\
\hline 2017 & 4.191 .100 & 4.736 .400 & $88,4 \%$ \\
\hline 2017 & $7,7 \% \quad 92,4$ & $5 \%$ & 4,62 \\
\hline \multicolumn{5}{|c}{ Sumber: Laporan Keuangan PT. Bank BCA Syariah Tbk. (Data Diolah) } \\
\hline
\end{tabular}

FDR pada PT. Bank BCA Syariah Tbk. per 31 Desember 2013 sebesar 83,4\%, tahun 2014 sebesar 91,1\%, tahun 2015 sebesar $91,4 \%$, tahun 2016 sebesar $90,1 \%$ dan tahun 2017 sebesar 88,4\%. Hal ini menunjukkan dari tahun 2013 hingga 2017 rasio FDR PT. Bank BCA Syariah Tbk. mengalami fluktuasi. Terjadinya penurunan rasio FDR ini menunjukkan adanya kenaikan dana yang disalurkan bank melalui pembiayaan.

Setelah melakukan perhitungan nilai rasio FDR, maka selanjutnya adalah melakukan analisis nilai kredit FDR pada PT. Bank BCA Syariah Tbk. tahun 2013-2017. 


\begin{tabular}{|c|c|c|c|c|c|}
\hline \multicolumn{6}{|c|}{ Tabel 27. Nilai Kredit Faktor FDR } \\
\hline Tahun & Rasio FDR & NK FDR & NK Maksimum & Bobot & NK Faktor \\
\hline 2013 & $83,4 \%$ & 126,4 & 100 & $5 \%$ & 5,00 \\
\hline 2014 & $91,1 \%$ & 95,6 & 95,6 & $5 \%$ & 4,78 \\
\hline 2015 & $91,4 \%$ & 94,4 & 94,4 & $5 \%$ & 4,72 \\
\hline 2016 & $90,1 \%$ & 99,6 & 99,6 & $5 \%$ & 4,98 \\
\hline 2017 & $88,4 \%$ & 106,4 & 100 & $5 \%$ & 5,00 \\
\hline \multicolumn{6}{|c|}{ Sumber: Laporan Keuangan PT. Bank BCA Syariah Tbk. (Data Diolah) } \\
\hline
\end{tabular}

Nilai Kredit FDR PT. Bank BCA Syariah Tbk. per 31 Desember 2013 sebesar 126,4, tahun 2014 sebesar 95,6, tahun 2015 sebesar 94,4, tahun 2016 sebesar 99,6, tahun 2017 sebesar 106,4. Oleh karena nilai kredit maksimum 100, maka nilai rasio FDR untuk tahun 2013, dan 2017 diakui sebesar 100, sedangkan pada tahun 2014, 2015, dan 2016 dibawah nilai maksimum maka nilai rasio FDR untuk tahun 2014 sebesar 96,32, tahun 2015 sebesar 95,36, dan tahun 2016 sebesar 4,98.

\section{Analisis Penilaian Tingkat Kesehatan Bank}

Setelah dilakukan perhitungan rasio kinerja keuangan pada PT. Bank BCA Syariah Tbk. Maka selanjutnya dilakukan penelitian kesehatan keuangan dengan metode CAMEL. Hal ini dimaksud untuk menilai apakah PT. Bank BCA Syariah Tbk dapat dikategorikan sehat.

Berdasarkan tingkat kesehatan rasio CAMEL menurut Bank Indonesia maka akan dilakukan perhitungan bobot dengan menggunakan metode CAMEL pada PT. Bank BCA Syariah Tbk tahun 2013 sampai dengan 2017 yang dapat dilihat pada tabel berikut ini:

\begin{tabular}{|c|c|c|c|c|c|}
\hline \multicolumn{7}{|c|}{ Tabel 28. Nilai Bersih Rasio CAMEL Tahun 2013} \\
\hline Kategori & Rasio & Rasio (\%) & NK & Bobot & Faktor \\
\hline Capital & CAR & $14,98 \%$ & 100,00 & $25 \%$ & 25,00 \\
\hline Assets & KAP & $0,41 \%$ & 100,00 & $25 \%$ & 25,00 \\
\hline Assets & PPAP & $102 \%$ & 100,00 & $5 \%$ & 5,00 \\
\hline Management & - & - & 100,00 & $25 \%$ & 25,00 \\
\hline Earnings & ROA & $0,82 \%$ & 54,66 & $5 \%$ & 2,73 \\
\hline Earnings & BOPO & $79,03 \%$ & 100,00 & $5 \%$ & 5,00 \\
\hline Liquidity & NCM-CA & $13,8 \%$ & 86,2 & $5 \%$ & 4,31 \\
\hline Liquidity & FDR & $83,4 \%$ & 100,00 & $5 \%$ & 5,00 \\
\hline \multicolumn{7}{|c|}{ Nilai Bersih Rasio CAMEL } \\
\hline
\end{tabular}

Tabel 29. Nilai Bersih Rasio CAMEL Tahun 2014
\begin{tabular}{|c|c|c|c|c|c|}
\hline Kategori & Rasio & Rasio (\%) & NK & Bobot & Faktor \\
\hline Capital & CAR & $28,67 \%$ & 100,00 & $25 \%$ & 25,00 \\
\hline Assets & KAP & $0,68 \%$ & 100,00 & $25 \%$ & 25,00 \\
\hline Assets & PPAP & $104 \%$ & 100,00 & $5 \%$ & 5,00 \\
\hline Management & - & - & 100,00 & $25 \%$ & 25,00 \\
\hline Earnings & ROA & $0,58 \%$ & 38,66 & $5 \%$ & 1,93 \\
\hline Earnings & BOPO & $86,66 \%$ & 100,00 & $5 \%$ & 5,00 \\
\hline Liquidity & NCM-CA & $-26,4 \%$ & 100,00 & $5 \%$ & 5,00 \\
\hline Liquidity & FDR & $91,1 \%$ & 95,6 & $5 \%$ & 4,78 \\
\hline \multicolumn{7}{|c|}{ Nilai Bersih Rasio CAMEL } \\
\hline Sumber: Laporan Keuangan PT. Bank BCA Syariah Tbk. (Data Diolah) \\
\hline
\end{tabular}

\begin{tabular}{|c|c|c|c|c|c|}
\hline \multicolumn{7}{|c|}{ Tabel 30. Nilai Bersih Rasio CAMEL Tahun 2015} \\
\hline Kategori & Rasio & Rasio $(\%)$ & NK & Bobot & Faktor \\
\hline Capital & CAR & $34,43 \%$ & 100,00 & $25 \%$ & 25,00 \\
\hline Assets & KAP & $0,99 \%$ & 100,00 & $25 \%$ & 25,00 \\
\hline Assets & PPAP & $101,7 \%$ & 100,00 & $5 \%$ & 5,00 \\
\hline Management & - & - & 100,00 & $25 \%$ & 25,00 \\
\hline Earnings & ROA & $0,72 \%$ & 48 & $5 \%$ & 2,4 \\
\hline Earnings & BOPO & $66,10 \%$ & 100,00 & $5 \%$ & 5,00 \\
\hline Liquidity & NCM-CA & $39,2 \%$ & 60,8 & $5 \%$ & 3,40 \\
\hline Liquidity & FDR & $91,4 \%$ & 94,4 & $5 \%$ & 4,72 \\
\hline \multicolumn{7}{|c|}{ Nilai Bersih Rasio CAMEL } \\
\hline
\end{tabular}

Tabel 31. Nilai Bersih Rasio CAMEL Tahun 2016

\begin{tabular}{|c|c|c|c|c|c|}
\hline Kategori & Rasio & Rasio (\%) & NK & Bobot & Faktor \\
\hline Capital & CAR & $22,00 \%$ & 100,00 & $25 \%$ & 25,00 \\
\hline Assets & KAP & $0,56 \%$ & 100,00 & $25 \%$ & 25,00 \\
\hline Assets & PPAP & $87,4 \%$ & 100,00 & $5 \%$ & 4,37 \\
\hline Management & - & - & 100,00 & $25 \%$ & 25,00 \\
\hline Earnings & ROA & $0,98 \%$ & 65,33 & $5 \%$ & 3,26 \\
\hline Earnings & BOPO & $61,90 \%$ & 100,00 & $5 \%$ & 5,00 \\
\hline Liquidity & NCM-CA & $11,9 \%$ & 88,1 & $5 \%$ & 4,40 \\
\hline Liquidity & FDR & $90,1 \%$ & 99,6 & $5 \%$ & 4,98 \\
\hline \multicolumn{6}{|c|}{ Nilai Bersin Rasio CAMEL } \\
\hline Sumber: Laporan Keuangan PT. Bank BCA Syariah Tbk. (Data Diolah) \\
\hline
\end{tabular}

\begin{tabular}{l}
\hline Tabel 32. Nilai Bersih Rasio CAMEL Tahun 2017 \\
\begin{tabular}{|c|c|c|c|c|c|}
\hline Kategori & Rasio & Rasio (\%) & NK & Bobot & Faktor \\
\hline Capital & CAR & $28,68 \%$ & 100,00 & $25 \%$ & 25,00 \\
\hline Assets & KAP & $0,56 \%$ & 100,00 & $25 \%$ & 25,00 \\
\hline Assets & PPAP & $108,1 \%$ & 100,00 & $5 \%$ & 5,00 \\
\hline Management & - & - & 100,00 & $25 \%$ & 25,00 \\
\hline Earnings & ROA & $1,04 \%$ & 69,33 & $5 \%$ & 3,46 \\
\hline Earnings & BOPO & $64,70 \%$ & 100,00 & $5 \%$ & 5,00 \\
\hline Liquidity & NCM-CA & $7,6 \%$ & 92,4 & $5 \%$ & 4,62 \\
\hline Liquidity & FDR & $88,4 \%$ & 100,00 & $5 \%$ & 5,00 \\
\hline Nilai Bersih Rasio CAMEL \\
\hline Sumber: Laporan Keuangan PT. Bank BCA Syariah Tbk. (Data Diolah) \\
\hline
\end{tabular}
\end{tabular}


Berdasarkan tabel-tabel diatas maka dapat disajikan hasil penilaian kesehatan keuangan dengan rasio CAMEL khususnya dalam tahun 2013 sampai dengan tahun 2017, yang dapat dilihat melalui tabel berikut ini:

\begin{tabular}{l}
\hline $\begin{array}{c}\text { Tabel 33. Hasil Penilaian Tingkat Kesehatan Keuangan } \\
\text { PT. Bank BCA Syariah, Tbk. Tahun 2013- 2017 }\end{array}$ \\
\begin{tabular}{|c|c|c|}
\hline Tahun & Nilai CAMEL & Predikat Tingkat Kesehatan \\
\hline 2013 & 97,04 & SEHAT \\
\hline 2014 & 96,71 & SEHAT \\
\hline 2015 & 95,52 & SEHAT \\
\hline 2016 & 97,01 & SEHAT \\
\hline 2017 & 98,00 & SEHAT \\
\hline \multicolumn{3}{|c|}{ Sumber: Laporan Keuangan PT. Bank BCA Syariah Tbk. (Data Diolah) } \\
\hline
\end{tabular}
\end{tabular}

Berdasarkan hasil perhitungan nilai bersih masing-masing rasio yang tertera dalam tabel diatas terlihat penjumlahan nilai bersih keseluruhan aspek (CAMEL) pada tahun 2013 sebesar 97,04, pada tahun 2014 sebesar 96,71, pada tahun 2015 sebesar 95,52, pada tahun 2016 sebesar 97,01, dan pada tahun 2017 sebesar 98,09. Berdasarkan kriteria penilaian tersebut maka hasil penilaian aspek CAMEL PT Bank BCA Syariah Tbk. pada tahun 2013 adalah SEHAT, tahun 2014 adalah SEHAT, tahun 2015 adalah SEHAT, tahun 2016 adalah SEHAT, dan tahun 2017 adalah SEHAT.

\section{SIMPULAN}

Nilai rasio CAR selama tahun 2013-2017 yang dicapai melebihi dari $8 \%$, sesuai dengan standar yang telah ditetapkan oleh Bank Indonesia. Nilai rasio KAP selama tahun 2013 sampai tahun 2017 yang dicapai tidak melebihi 15,5\%, sesuai dengan standar yang telah ditetapkan oleh Bank Indonesia. Dalam penelitian ini analisis rasio manajemen tidak dilakukan karena adanya keterbatasan yang ada pada saat dilakukan nya penelitian. Pembatasan ini dilakukan mengingat bahwa untuk dapat melakukan penilaian tingkat kesehatan pada bank syariah dengan menggunakan metode CAMEL, tidak cukup hanya mendasarkan pada analisis yang tertuju hanya terhadap laporan keuangan yang dipublikasikan saja, tetapi juga data-data pendukung lainnya yang bersifat internal.
Data yang berhubungan dengan aspek manajemen tidak dapat diperoleh hanya dengan menggandalkan dari data publikasi bank syariah tersebut, tetapi harus melalui survei kuisioner dan wawancara. Di Indonesia hanya Bank Indonesia dan bank yang bersangkutan saja yang dapat mengetahuinya. Nilai rasio BOPO selama tahun 2013 hingga tahun 2017 yang dicapai tidak melebihi $100 \%$, sesuai dengan standar yang telah ditetapkan oleh Bank Indonesia. Nilai rasio FDT selama tahun 2013 hingga tahun 2017 yang dicapai tidak melebihi 115\%, sesuai dengan standar yang telah ditetapkan oleh Bank Indonesia.

\section{PENGHARGAAN}

Pada kesempatan kali ini penulis ingin mengucapkan terimakasih kepada semua yang terlibat baik secara langsung maupun tidak langsung yang tidak bisa penulis sebutkan satu persatu. Terimakasih atas saran, masukan, dan bantuan, semoga penelitian ini bisa bermanfaat bagi semua pihak.

\section{DAFTAR PUSTAKA}

Bank Indonesia. Surat Edaran No.6/23/PPNP Tanggal 31 Mei 2004. Perihal Tata Cara Penilaian Kesehatan Bank. Jakarta.

Bank Indonesia. Surat Keputusan Direksi Bank Indonesia No.26/67/KEP/DIR tanggal 28 Februari 1991. Perihal tentang Kewajiban Penyediaan Modal Minimum Bank. Jakarta.

Bank Indonesia. Peraturan Bank Indonesia No 6/10/PBI/2004 Tanggal 12 April 2004. Perihal Sistem Penilaian Kesehatan Bank. Jakarta.

Dendawijaya, L. (2009). Manajemen Perbankan. Jakarta: Ghalia Indonesia.

Kasmir. (2008). Bank dan Lembaga Keuangan Lainnya. Jakarta: PT Raja Grafindo Persada.

Pandria, F. (2012). Manajemen Dana dan Kesehatan Bank. Jakarta: PT Rineka Cipta..

Riyanto, B. (2010). Dasar-dasar Pembelajarn Perusahaan, Edisi Keempat. Yogyakarta: BPFE.

Santoso, T. B. (2006). Bank dan Lembaga Keuangan lainnya, Edisi 2. Jakarta: Salemba Empat.

Sartono, A. (2010). Manajemen Keuangan Teori dan Aplikasi, Edisi keempat. Yogyakarta: 
BPFE.

Schaik. (2001). Pengertian Bank syariah. Diakses pada tanggal 26 April 2018 pukul 20.47 (http://bit.ly/2dbrUFS).

Sugiyono, (2011). Metode Penelitian Kuantitatif Kualitatif dan ReDD. Bandung: Alfabeta.

Undang-Undang Nomor 7 Tahun 1992 Tentang Perbankan.
Undang-Undang Nomor 10 Tahun 1998 Tentang Perubahan Atas Undang-Undang Nomor 7 Tahun 1992 Tentang Perbankan.

Undang-Undang Nomor 21 Tahun 2008 Tentang Perbankan Syariah.

Undang-Undang Nomor 23 Tahun 1999 Tentang Bank Indonesia. 